\title{
Management of blossom blight and leaf anthracnose of mango using fungicides
}

ASHISH KUMAR* AND SHIV CHARAN SOLANKI

Department of Plant Pathology, College of Agriculture, Jawaharlal Nehru Krishi Vishwavidyalaya, REWA (M.P.) INDIA

\section{ARITCLE INFO}

Received : 14.06 .2014

Revised : 03.09 .2014

Accepted : 14.09 .2014

\section{KEY WORDS :}

Mangifera indica, Fungicides, Blossom blight, Anthracnose

Email: ashishashish2612@gmail.com

\begin{abstract}
In the present investigation, efforts were made on the evaluation of different fungicides (systemic, non-systemic and combination of both) against blossom blight and leaf anthracnose of mango under natural conditions. Pooled analysis of three years data indicated that three foliar sprays with a combination of non-systemic and systemic fungicide (carbendazim + mancozeb at $0.2 \%$ ) at 10 days interval starting from initiation of disease symptom was found most effective in controlling both the diseases. Using this fungicide, blossom blight and anthracnose can be inhibited upto more than 75 per cent. However, among other tested fungicides, tricyclazole $(0.1 \%)$ treatment resulted in mean PDI of 9.31 per cent and 8.31 per cent for blossom blight and anthracnose, respectively and was recorded as second to carbendazim + mancozeb $(0.2 \%)$ in controlling the two diseases.
\end{abstract}

How to view point the article : Kumar, Ashish and Solanki, Shiv Charan (2014). Management of blossom blight and leaf anthracnose of mango using fungicides. Internat. J. Plant Protec., 7(2) : 453-455. 